\title{
Italia como referente de modernidad. El eco de la revista Valori Plastici y del grupo Novecento en el arte español de postguerra
}

\author{
Laura Arias Serrano \\ Universidad Complutense de Madrid
}

RESUMEN. El presente estudio analiza el influjo que, en los años cuarenta, ejerció en los artistas españoles -y, entre ellos, en el pintor Juan Antonio Morales- el arte italiano, y en concreto el nacido al abrigo de la revista Valori Plastici (1918-1922), una publicación que surgió con el propósito de unir a la auténtica tradición italiana, el moderno lenguaje figurativo de Cézanne o del cubismo: actitud bastante ambigua que les permitía ser modernos sin perder por ello su identidad nacional. Precisamente la huella de estos artistas italianos -y de sus continuadores: el grupo Novecento-, es la que este artículo intenta descubrir, rastreando para ello en la obra de aquellos jóvenes pintores españoles que, aislados del exterior y sin saber con exactitud si lo que hacían era, a escala europea, vanguardia o retaguardia, se verían obligados a recuperar, bajo el signo estético del eclecticismo, los viejos idearios prebélicos.

Palabras clave: Valori Plastici, grupo Novecento, "retorno al orden", Nueva Objetividad, Realismo mágico, pintura española de postguerra, Juan Antonio Morales.

ABSTRACT. The present study analyse the influence Italian art exerted on Spanish artists in the 1940's -and, between them, the painter Juan Antonio Morales-, with particular attention to Italian art publicised and promoted in the magazine Valori Plastici (1918-1922). This publication was founded on the proposition of combining authentic Italian tradition with the modern figurative language of Cezanne and Cubism, a fairly ambiguous attitude that permitted them to be modern without losing their national identity in the process. The intention of this study is to examine the precise impact of these Italian artists - and of their followers, the Novecento group-, on the work of young Spanish painters, who, due to their isolation from foreign influences and unsure if their work was, at the European level, vanguard or outdated, had no choice but to dust off, under the aesthetic mantle of eclecticism, older pre-war ideas.

Key Words: Valori Plastici, group Novecento, "return to order", New Objectivity, Magic Realism, post-war Spanish painting, Juan Antonio Morale.

El propósito de este artículo no es otro que reflexionar sobre la situación que vivieron nuestros jóvenes artistas de vanguardia, en ese periodo surcado de luces y sombras que fue la posguerra española. Un asunto amplio y complejo que en esta ocasión hemos querido centrar en una pregunta: ¿fue la Italia de entreguerras un importante referente para aquellos artistas que, habiendo iniciado su andadura vanguardista antes del conflicto, se dieron de bruces con una situación nueva de aislamiento y general mediocridad?

Al hablar de la Italia de entreguerras, no podemos ignorar que después de la I Guerra Mundial, el arte se vio tentado a un retorno a las apariencias, a una llamada al orden como si la vida impusiera sus derechos 
después de las grandes pruebas a que la guerra la había sometido, como si después del triunfo de la irracionalidad, se sintiera la necesidad de volver a confiar en los valores de la razón.

En este proceso de profunda revisión, en el que los artistas europeos volverían sus ojos a sus propias raíces culturales y al arte de los antiguos maestros, el país pionero por excelencia será Italia. Basta recordar que ya en 1918, y como portavoz del movimiento metafísico, había nacido en Roma la revista Valori plastici, con el propósito de unir a la auténtica tradición italiana -la de Giotto, Masaccio o Piero della Francesca- el lenguaje figurativo moderno, el de Cézanne y el del cubismo, considerado como la raíz de todo el arte europeo. Actitud bastante ambigua ${ }^{1}$ que permitirá a los artistas asociados a ella, en su mayoría metafísicos, como De Chirico, Carrá, Arturo Martini o Giorgio Morandi, seguir considerándose modernos sin por ello perder su identidad nacional.

En el resto de Europa esta llamada al orden, esta idea de pureza, sencillez y claridad también acabará generalizándose. De hecho, en 1921, cuando Boglio organiza en Alemania varias exposiciones itinerantes del grupo Valori Plastici, la muestra despierta gran interés entre los artistas alemanes, que por esas fechas se estaban encaminando hacia un tipo de arte que privilegiaba el objeto representado con toda nitidez. $\mathrm{Y}$ prueba de ello será la aparición de la Nueva Objetividad o Neue Sachlichkeit ${ }^{2}$, que sería

\footnotetext{
${ }^{1}$ Aunque la revista Valori Plastici, nacida como órgano de la Pintura Metafísica, parecía, en un principio y de cara al exterior, interesada en las vanguardias extranjeras, acabó centrando su atención en la tradición clásica italiana. Algo que será fruto, más que de un obstinado nacionalismo, de una concepción idealista del arte como clásico universal y eterno.

${ }^{2}$ Expresión que se debe a Gustav Hartlaub, director de la Kunsthalle de Mannheim, quien alrededor de esta idea de creación de una nueva realidad, organizó en
}

teorizada a comienzos de los años veinte por Franz Roh en su libro Post Expresionismo. Realismo Mágico. Problemas de la nueva pintura europea. ${ }^{3}$

El mismo Roh explica que el término Realismo Mágico no define un estilo ni un movimiento, sino más bien un clima cultural común de vuelta a la realidad, un panorama en el que, tras proponer algunas líneas de investigación ${ }^{4}$, vuelve a llevarnos a Italia, situando las teorías y resultados de Valori Plastici como el punto central de todo el movimiento europeo. Una corriente de opinión que, en las fechas en que Roh escribe esto, ya se había transformado en el grupo Novecento.

Recordemos que, cuando la experiencia de Valori Plastici concluye en 1922 año en que se publica el último número de la revista, el no $15-$, la labor de estos artistas, interesados en la vuelta al orden, se verá

el verano de 1925, en el Palacio de Arte de Mannheim, una exposición bajo el nombre de Nueva objetividad.

${ }^{3}$ Vid. F. ROH, Nach-Expressionismus, Magischer Realismus. Probleme der neuesten europäischen Malerei, Leipzig, 1925 [traducción al castellano de Federico Vela, Realismo Mágico. Post Expresionismo, Madrid, 1927].

${ }^{4}$ Roh, tomando como referencia lo que se estaba realizando en esta dirección en Francia, Italia y Alemania, llama nuestra atención sobre distintas formas de entender la obra de arte: una vuelta a la cultura de la pintura (Derain), la recuperación del linealismo más extremo (Beckmann), la elección de un neoclasicismo de origen constructivista (Schlermmer) o purista (Ozenfant), el rechazo de la modernidad y el diálogo con la tradición clásica (De Chirico, Carrà y todo el grupo de Valori Plastici, así como Davringhausen, Mense y Schrimpf), la adhesión a un sueño primitivo y originario, del que el Aduanero Rousseau había sido su abanderado (Spies), y finalmente una lectura verista, casi despiadada, de la realidad objetual (Dix, Grosz, Schlichter y Hubbuch). [Vid. C. GIAN FERRARI, "El Realismo Mágico y la función desempeñada por los artistas italianos", en Catálogo de la exposición Realismo. Franz Roh y la Pintura Europea 1917-1936, Valencia, 1997, p. 83]. 
continuada por el grupo milanés Novecento ${ }^{5}$ (Gruppo de Sette Pittori del Novecento). Un grupo que, en torno a la crítica Margherita Sarfatti, nace con un propósito claro: luchar contra los excesos de una vanguardia que había roto todo vínculo con la historia nacional, y dar a Milán el protagonismo del arte italiano. Para ello sus componentes ${ }^{6}$ intentarán un retorno al clasicismo de la época de Augusto, creando un estilo monumental y solemne muy adecuado a los fines políticos que perseguían: ser los intérpretes oficiales de la nueva Italia nacida del fascismo. Prueba de ello es que, durante la primera exposición del grupo en la Galería Pesaro de Milán, en 1923, Mussolini pronunció una alocución sobre el tema de "el arte y el gobierno". A partir de ese momento Novecento tenderá a convertirse en un arte de carácter oficial, que asume como hecho necesario su pacto con el poder.

Tales circunstancias son las que hoy nos llevan a pensar que tanto Valori plastici como Novecento fueron las corrientes que mejor se amoldaron al sentir general de gran parte de los artistas e intelectuales españoles de los años cuarenta, que, como la Italia de Mussolini, vivían una época de retorno a la gran tradición nacional ${ }^{7}$.

Una prueba del interés que, en estos años de la posguerra, existía en España por el arte italiano, fue la Exposición de Arte

\footnotetext{
${ }^{5}$ El término Novecento lo pusieron de moda, en 1922, una serie de pintores, emulando la costumbre muy italiana, desde el Trecento, de designar su pintura por períodos centenarios.

${ }^{6}$ E 1 grupo Novecentista reunió inicialmente a Piero Marussig, Ubaldp Oppi, Anselmo Bucci, Mario Sironi, Leonardo Dudreville, Gian Emilio Malerba y Achille Funi.

${ }^{7}$ Esta cuestión fue tratada por primera vez por la autora en "El retorno al orden y la utopía clásica. Una alternativa para los jóvenes artistas de la posguerra española. Un caso concreto y una reflexión", Actas del Congreso Dos Décadas de Cultura Artística en el Franquismo (1936-1956), vol. I, Universidad de Granada, 2001, pp. 307-336.
}

Contemporáneo Italiano celebrada en Madrid en 1948. Muestra en la que figuraban todos aquellos artistas que durante años habían servido de referencia a los jóvenes artistas españoles: Campigli, Carrà, Casorati, De Chirico, De Pisis, Guttuso, Maffai, Manzú, Marini, Martini, Modigliani, Morandi, Rosai, Sassu y Sironi.

Centrándonos ahora en el tema que nos ocupa, retrocedemos para ello al año 1939. En España se iniciaba la posguerra, tiempos difíciles de incertidumbre económica, atonía cultural, sorda violencia social y triunfalismo político, durante los que el país sufriría un proceso de regresión a todos los niveles. En este periodo surcado de luces y sombras es donde intentaremos centrar nuestras reflexiones sobre el posible influjo que estas ideas, importadas de Italia, ejercieron en el arte de nuestros jóvenes artistas de vanguardia.

Como límites cronológicos no hemos querido ir más allá de 1944, al considerar que fueron estos los años de mayor dureza y aislamiento para España. Luego, conforme avanza la década, $\mathrm{y}$, sobre todo, a partir de 1948, momento en que los debates artísticos españoles empiezan a coincidir con los internacionales, puede hablarse ya de un intento serio por incorporar nuestro arte al devenir de la vanguardia. Pero eso, ya es otra historia...

Dado que resulta imposible encontrar una respuesta única para todos los casos, nos parece oportuno tomar como referencia a uno de aquellos jóvenes artistas: el pintor vallisoletano afincado en Madrid, Juan Antonio Morales (1909-1984), y caminar de su mano con el fin de ver qué tipo de respuesta pudo dar a su arte. Sin olvidar que Morales pertenecía a ese grupo bastante numeroso de artistas -republicanos o simplemente antifranquistas-, que por su juventud, escasa relevancia o simple buena suerte pudieron reanudar, tras algún tiem- 
po de depuración o cárcel, su actividad en condiciones de extrema dureza, pero con el tesón suficiente para conseguir al cabo de los años cierta influencia en torno suyo.

Pero veamos ahora cuál fue su historia... Para ello debemos trasladarnos a aquella cálida mañana del 18 de julio de 1936, cuando en la madrileña Cervecería de Correos, encontrándose celebrando con un grupo de amigos su recién ganada plaza de profesor de Dibujo, se enteró a través de la radio de la sublevación militar en Marruecos. Tras el desconcierto inicial vendría su compromiso con uno u otro bando. Sabía que algunos de sus amigos más entrañables $\mathrm{y}$, sobre todo, sus familiares estaban en la zona nacional, pero intelectualmente tenía claro que su lugar estaba al lado de la República. Más aún si tenemos en cuenta que en los años precedentes se había movido en el ambiente más dinámico y progresista del momento, nutriéndose de las enseñanzas de los intelectuales y artistas que ahora se congregaban en torno al gobierno democrático. También de la noche a la mañana, en el terreno artístico, se encontró ante una situación absolutamente nueva, que le obligaría a realizar un tipo de arte cuya finalidad iba más allá de lo individual para buscar un objetivo colectivo mucho más elevado. Nos referimos a su tarea como cartelista de guerra e ilustrador gráfico, una labor que, realizada esporádicamente, fue su medio de vida durante la contienda.

Con el final de la guerra vendría la inevitable depuración, primero en la cárcel madrileña de Carabanchel y luego, en la de Porlier, situada en la calle General Pardiñas. Aunque se le acusaba de ser rojo, de haber estado relacionado con el mundo propagandístico antifascista e incluso de haber realizado caricaturas de Franco $^{8}$, no

\footnotetext{
${ }^{8}$ En relación con esto hay que decir que una obra de la que no se habló, pero que en todo momento estuvo presente en la mente de los que participaron en
}

pudieron hallarse pruebas en su contra, de ahí que tras un año de cárcel fuera puesto en libertad.

En un principio acarició la idea de marchar a Cuba, en donde por aquel entonces residía su familia, pero finalmente decidió reconstruir su mundo en España, escenario de sus buenas vivencias de antaño, pero también de sus recientes fracasos. Su decisión no implicaba que se sintiera identificado con el nuevo régimen, pero el cansancio que arrastraba y su búsqueda de una existencia en paz, le harían elegir el camino que menos conflictos podía acarrearle y el que pensaba que, más prontamente, le ayudaría a olvidar la tremenda pesadilla de la guerra; y éste no era otro que el lento camino de la integración. Estaba claro que la guerra que a unos fusiló y a otros exilió, a Juan Antonio Morales lo asimiló, como también lo asimilaría la situación surgida al finalizar ésta.

A mediados de 1940 el joven pintor volvía a tener en sus manos las riendas de su vida, en un Madrid enrarecido por la carestía, el racionamiento y el mercado negro, y que tan admirablemente recrearía, años después, Camilo José Cela en su obra La Colmena,

En el terreno personal la guerra había dado al traste con sus visitas a la Residencia de Estudiantes, la vida de tertulia y los tan añorados trabajos en colaboración con Pepe Caballero, el amigo al que Morales se sentía muy unido, a pesar de que la guerra los había situado en zonas opuestas y les había encomendado diferentes destinos ${ }^{9}$. Pero

la depuración, fue el cartel titulado Los Nacionales (Ministerio de Propaganda). Su decisión de no firmarlo, le salvaría la vida.

${ }^{9}$ Pepe Caballero, a quien el alzamiento cogió en Huelva, pasó toda la guerra en zona nacional, trabajando también en distintos proyectos culturales y propagandísticos. Sirva como muestra su labor en el grupo de teatro onubense La Tarumba o en las repre- 
ahora de nuevo estaban en el mismo barco, como parece desprenderse de estas palabras de Caballero:

"Ya nada era lo que había sido. Hicimos recuento de todo lo pasado y de lo que nos quedaba por delante, y en aquella vigilia de la postguerra comprendimos que no nos quedaba otro camino que volver a empezar de nuevo, a partir de ce$r o^{\prime \prime 10}$.

En este ambiente, la situación personal y profesional de Morales podía haber llegado a ser dramática, si Pepe Caballero, que entonces militaba en la Falange, no le hubiera puesto en contacto con Dionisio Ridruejo $^{11}$, quien, conociendo la labor cartelística del joven pintor durante la guerra, nada más salir de la cárcel, lo llamó para que colaborara en la Jefatura Nacional de Propaganda que él dirigía. Allí, en el Departamento de Plásticas se dedicó a organizar tribunas y reposteros para distintos actos conmemorativos o de exaltación patriótica.

Estaba claro que la España de la Crema Numantina de Visnú, o de los peinados Arriba España pocos alicientes podía ofrecer al joven Morales, que pese a todo, siguió pintando en la soledad de su estudio, soñando con todo aquello que aún no conocía, y con la esperanza de poder retomar quizá algún día lo aprendido tiempo atrás, para darle una interpretación acorde con

sentaciones de autos sacramentales castellanos, en las que se trataba de resucitar el espíritu de La Barraca o de las Misiones Pedagógicas.

10 J. CABAllero, "Juan Antonio Morales", en AAVV., Catálogo de la exposición Homenaje a Juan Antonio Morales, Banco de Bilbao, Madrid, 1984, p. 37.

${ }^{11}$ Dionisio Ridruejo, fundador de la revista Escorial (1940) y uno de los primeros seguidores de José Antonio Primo de Rivera, desempeñaba por aquel entonces un destacado papel en el campo de la información y propaganda del régimen, lo que no evitó que criticara la intolerancia que el aparato estatal ejercía sobre el campo de la cultura y de los medios informativos. los tiempos. ¡Vanas esperanzas aquellas! Vanas porque no tenían en cuenta el poder de succión que un medio como el Madrid de comienzos de los cuarenta iba a tener en el carácter débil y moldeable del joven pintor.

No podemos olvidar que en el aspecto cultural se iniciaba ahora un proceso regresivo de provincianización y de general mediocridad $^{12}$, ya que a la ausencia de importantes nombres de la pintura e intelectualidad española ${ }^{13}$, se unía el deseo de recuperar aquel academicismo triunfante de los años veinte, personificado ahora en pintores ${ }^{14}$ que desdeñaban sistemáticamente todo lo que pudiera proceder de los años republicanos, sumidos a su entender en el caos político y espiritual.

Morales, que en los años de la preguerra parecía haber hallado la senda de su vocación, se encontraba ahora perdido y desconcertado. Sabía, además, que en un principio le sería imposible vivir sólo de su pintura, y más aún si pensamos que el mercado del arte, en su mayoría de encargo,

${ }^{12}$ El español medio, como bien apunta Tuñón de Lara, se creía situado fuera del mundo. Por añadidura la lectura era cara y difícil de encontrar; Unamuno y Galdós, Baroja y Blasco Ibáñez, Balzac y Stendhal estaban prohibidos. $\mathrm{Y}$ en las vitrinas de las librerías, junto a Maeztu, Vázquez de Mella y el Fundador, lucían las novelas extranjeras de Lajos Zilahy o de Dafne de Maurier o las españolas de Carmen de Icaza. [Vid. "Cultura e ideología" en M. MUÑón DE LARA (coord.), Historia de España, Barcelona, 1982, Vol. X, p. 458].

${ }^{13}$ Por estas fechas, como dice Hugh Thomas, "... a los mejores escritores españoles se les podía escuchar en la BBC de Londres o dando conferencias en México, o se les veía discutiendo en cafeterías de países latinoamericanos. En un sentido puramente estético la comunidad española desterrada fue una de las exportaciones más grandes cedidas por un país entonces profundamente dividido..." [Vid. H. THOMAS, La Guerra Civil Española, Madrid, 1980, vol. VI, p. 13].

${ }^{14}$ Nos referimos a pintores como Álvarez de Sotomayor, Julio Moisés, López Mezquita, Moreno Carbonero, Eugenio Hermoso, Marceliano Santa María, Llorens, Valentín de Zubiaurre o Gabriel Morcillo. 
estaba dirigido a una clientela conservadora, alérgica, por lo general, a todo lo que sonara a vanguardia.

Fue entonces cuando, forzado a subsistir en la diaria aceptación de un destino que le resultaba indiferente, decidió abrir, junto con el arquitecto José Mauro Murga, una Academia de Dibujo y Pintura, a la que pusieron el nombre de $J U M A^{15}$, y en la que Juan Antonio impartía clases de pintura y José Mauro de dibujo. Un improvisado y modesto centro de enseñanza que duraría muy poco, pues la situación de carestía general hacía difícil que cuajaran iniciativas de este tipo. Fue ésta la razón de que los dos amigos terminaran convirtiendo el local en una Sala de Exposiciones, que regentaría Murga y en la que Morales expondría por primera vez, algunas de sus obras, pues el joven pintor se había dado cuenta de que no le bastaba con su silencioso trabajo de taller, sino que debían buscar un cauce de expansión a su pintura organizando exposiciones por cuenta propia.

Serán precisamente estas primeras exposiciones de la posguerra las que nos sirvan de referencia a la hora de estudiar su trayectoria, pues en ellas encontramos las obras que mejor reflejan su propio bagaje personal, su capacidad de maniobra en un ambiente para nada receptivo a lo novedoso, $y$, sobre todo, hasta qué punto su pintura acusó el influjo de este retorno al orden al que antes aludíamos.

Un ejemplo lo tenemos en la exposición celebrada, en el verano de 1942, en la

\footnotetext{
15 Esta academia, cuyo nombre estaba formado por las dos primeras letras de Juan y Mauro, se situaba en un entresuelo alquilado de la calle Génova 21, tan profundo que permitió que en la parte trasera se instalara, con su mujer y su hijo, el pintor Rafael Botí. Como dato anecdótico Rafael Botí, hijo, nos contaba que, cuando alguien venía a inscribirse, él, que todavía era un niño, solía meterse en la poco concurrida academia, para hacer bulto.
}

Galería JUMA, en la que Morales, junto a José Caballero, Víctor Cortezo y Luis Calzada, lograría atraer a la hasta entonces inalcanzable crítica, como paso necesario para darse a conocer en los círculos artísticos de la capital.

Pero ¿qué obras son éstas que, a tan sólo tres años de finalizar la guerra, el joven pintor, solo y aislado del exterior, presentaba en JUMA? Las pinturas, todas ellas de muy variada temática -composiciones, academias, desnudos, paisajes con figuras y bodegones-, pese a conservar aún el recuerdo de su arriesgada aventura de antaño, como era esa armadura neocubista, o ese aire surreal que habían marcado su producción anterior, acusaban ya un cambio: una clara tendencia al figurativismo, minucioso en la técnica y clasicista en el contenido. Sus obras surgen ahora con mucha más precisión que en los años treinta, bañadas por una luz gélida y enigmática, a la vez que envueltas por un silencio y una quietud casi sobrenaturales.

Una muestra la tenemos en su obra Cabeza Clásica ${ }^{16}$ (c.1941-1942) (Lám.1), clara evocación de aquellas hieráticas y realistas esculturas togadas, propias de la antigüedad romana, pero que ahora, estática y silenciosa, emerge de la oscuridad con una apariencia ambigua, entre pétrea y humana, muy cercana a lo suprarreal. Rasgos que nos acercan a algunos artistas italianos, que quizá Morales sólo conocía a través de ilustraciones o fotografías de algún catálogo o revista especializada. Tal es el caso del novecentista Felice Casorati, cuya Naturaleza muerta con maniquies (Lám.2), de 1924, irradia una atmósfera tan gélida e inquietante, que cualquier referencia a la realidad acaba transformándose en algo puramente mental. Frialdad que en Morales se dulcifica

\footnotetext{
${ }^{16}$ En el catálogo de la exposición de JUMA aparece con el no 3 y bajo el título: Cabeza.
} 
gracias a esa suculenta paleta entonada en ocres, grises y verdosos que será una constante de estos años. Pero lo más interesante es que estas dos obras de estudio, separadas en el tiempo más de quince años, sin duda comparten un mismo afán por objetivar la realidad, o lo que es lo mismo, ese deseo de vuelta al orden, que había triunfado en la Europa de entreguerras, y que ahora empezaba a ser moneda común en la España de los cuarenta.

Este moderno clasicismo, que antaño había propugnado la revista Valori Plástici, lo encontramos de nuevo en JUMA ${ }^{17}$, concretamente en su obra Composición con figuras (c.1941-1942) (Lám.3). Un cuadro enigmático, cuya esencia parece estar en la calidad del silencio y en la inmovilidad, así como en la forma en que los personajes: un maniquí hueco y sin ojos -que sugiere la confusión entre lo vivo y lo muerto- y una ambigua figura de mujer con un gran tocado, descansan en un espacio puramente mental, en el que no podía faltar la puerta del fondo, abierta a un mundo mágico por donde camina una etérea figura de mujer. Esta obra, al igual que la de su amigo José Caballero, Interior con personajes (c.1945) (Lám.4), nos acercan a Giorgio De Chirico, quien al crear en 1913, como estética de la negatividad, la pintura metafísica ${ }^{18}$, había puesto parte de los cimientos de esa vuelta $a$ la figuración. Años después, este mismo artista se convertiría en uno de los más destacados colaboradores de la revista Valori Plastici.

Algo separa, sin embargo, al pintor español del italiano, y es el no poder prescindir de los valores puramente pictóricos,

\footnotetext{
${ }^{17}$ En el catálogo de la exposición de JUMA aparece con el no 2 y bajo el título: Composición.

${ }^{18}$ Para De Chirico el arte era pura metafísica, no tiene relación con la realidad pues no persigue fines prácticos, de ahí que su presencia sea ambigua, inquietante y contradictoria.
}

como también le había ocurrido a Carlo Carrá, quien en 1929 se uniría al grupo Novecento, más comprometido que nunca en animar con acentos románticos los valores plásticos tradicionales. De igual modo, Morales, como otros muchos jóvenes artistas españoles, se hará eco de esta llamada al orden de una manera ecléctica y personal, aproximándose en cuanto a la técnica y a los temas a Valori Plastici, y en cuanto al magicismo y al tratamiento del espacio al Realismo Mágico. Lo que no quita que en términos generales siempre se sintiera mucho más cerca de lo latino que de lo germánico, de lo clásico que de lo patético, no sólo por su propio temperamento, sino por el tipo de estética que imperaba por aquellos años en España.

En este sentido, aunque no existió una arte propiamente franquista, entre otras cosas porque el régimen de Franco apenas valoró la obra de arte como instrumento político -a diferencia de lo que hicieron los fascismos alemán e italiano-, sí se advierte, entre un reducido grupo de artistas e intelectuales de derechas, un deseo de buscar una estética propia para el Régimen.

Para ello no dudarán en tomar como referencia la pintura italiana de entreguerras, aquella que conectaba directamente con el entorno de Valori Plastici y el grupo Novecento,

“... tendencias -señala Ángel Llorente- con las que el fascismo de Mussolini se relacionó por su mitificación de la historia de Italia, que entroncaba con el retorno al clasicismo y la defensa de la tradición nacional [...]. Pero salvo en el caso de unos pocos artistas que conocían esta ideología por haber residido en Italia, el 
parentesco fue más formal que ideológico"19.

También Cirici Pellicer, abundando en este tema, apunta que a lo largo de los años azules (1939-1951) y sobre el anquilosado panorama pictórico español,

"... vino a engancharse el influjo del arte italiano, el único arte moderno del que se tuvo noticias. Podemos atribuir a este contacto la metafísica arcaizante de los indalianos de Almería, el decorativismo mural de Javier Clavo y el aspecto a lo Campigli de las ilustraciones de Lara $y$ de sus composiciones murales para el Teatro Nacional" ${ }^{\prime 20}$.

Lo cierto es que muy al comienzo de la postguerra ya hubo claros intentos, por parte de los intelectuales falangistas de avanzada, de orientar el arte hacia un vanguardismo de espíritu clásico-mediterráneo, teñido, eso sí, de aire imperialista, y cercano a lo propugnado por el novecentismo italiano. Un ejemplo lo tenemos en el discurso pronunciado por el intelectual y político falangista Rafael Sánchez Mazas, en 1940, en el Museo de Arte Moderno de Madrid, y en donde entre otras cosas, decía:

"No os pido cuadros patrióticos, ni mucho menos patrioteros $y$ aduladores, sino cuadros que a la mente y a los sentidos traigan un reflejo del orden luminoso que queremos para la Patria entera. [...] No pintéis las lacras de la Patria, ni tampoco reunáis cachivaches caseros en un desorden subversivo, que luego llaman naturalezas muertas... No olvidéis que nuestra pintura mediterránea es una pintura cara al sol, cara al mar azul por

\footnotetext{
19 Á. LLORENTE, "Pertrechos visuales de una posguerra", en el catálogo de la exposición Tránsitos. Artistas españoles antes y después de la guerra civil, Caja de Madrid, Madrid, 1999, p. 49.

20 A. Cirici PEllicer, La Estética del Franquismo, Barcelona, 1977, pp.177-178.
}

donde nos vinieron las ideas solares de Jonia y de la Magna Grecia..." ${ }^{21}$.

A la vista de estas palabras, no puede pasarnos desapercibido el paralelismo existente entre Novecento y las teorías clasicistas del filósofo e historiador Eugenio D'Ors, en las que propugnaba la vuelta a la tradición y la defensa del clasicismo mediterráneo. A esto hay que añadir que, en la inmediata posguerra, junto al libro de Franz Roh -que pronto encontraría devotos lectores entre los pintores de vanguardia-, en España saldría también a la luz, Arte de entreguerras, una recopilación de artículos, publicados entre 1919 y 1936, en los que D'Ors planteaba sus propuestas tendentes a exaltar el orden, la disciplina, la construcción, en una línea bastante cercana a lo que había hecho allá por los años veinte el crítico alemán.

Pero, aunque este tipo de vanguardismo clasicista sirvió de referencia a muchos jóvenes artistas, no ocurriría lo mismo con otras estéticas, aunque más rompedoras, menos proclives a la exaltación patriótica:

“... esta ideología -dice Calvo Serraller-, aún sin llegar jamás a convertirse en un estilo dominante, ciertamente se reflejó en buena parte del arte español de los cuarenta y parte de los cincuenta, que significativamente se italianizó... Peor suerte tuvo, sin embargo, la facción artística que quiso hacer valer los, por otra parte, mucho más sólidos derechos de la Escuela de París, cuyos principales protagonistas fueron -entonces- Daniel Vázquez Díaz y Pancho Cossio, ambos paradójica y significativamente menospreciados. [...] Pero si el clasicismo novecentista italiano venció a la Escuela de París, tampoco los partidarios de aquél se pudieron ceñir demasiados laureles, pues

\footnotetext{
${ }^{21}$ R. SÁNCHEZ MAZAS, "Textos para una política de arte", en Escorial no 24, Madrid, octubre, 1942.
} 
ni unos ni otros despertaron el interés de la España oficial, ni de la que después se ha dado en llamar la España real, muy alejada entonces de cualquier tipo de preocupación artística de vanguardia" ${ }^{22}$.

Sea cual sea la incidencia social de este tipo de estéticas de avanzada, lo que es indudable es que en Morales, como en su amigo Caballero y tantos otros, la llamada al orden condiciona buena parte de su obra, lo que nos lleva a preguntarnos si hubo alguna fuente concreta -aparte de ilustraciones aparecidas en publicaciones especializadasque ahora, en estos años, les sirviera de referencia.

Salvando las distancias de estilo y finalidad, creemos que sería interesante detenernos en el ambiente que se respiraba en el Departamento de Plásticas. Sección de Información y Propaganda, de la Vicesecretaría de Educación Popular, de la F.E.T. y de las J.O.N.S.

Un organismo, con sede en la calle Fernando el Santo, en donde Morales trabajaría hasta bien avanzada la década en el ornato de distintos actos conmemorativos o de exaltación patriótica, concentraciones falangistas o desfiles militares, muy frecuentes en la primera etapa de la posguerra, un periodo marcado por el predominio de lo militar y por la consolidación de las principales constantes iconográficas del franquismo. Una iconografía que, al igual que ocurría en Alemana o en la Italia mussoliniana, afloraría en tribunas, reposteros o arquitecturas efímeras donde los gallardetes con banderas y estandartes, los pedestales para emblemas -como la $\mathrm{V}$ de la victoria, la corona de laurel o el yugo y las flechas-,

\footnotetext{
${ }^{22}$ F. CAlvo Serraller, "¿Aislamiento internacional o vacío social? Reflexiones sobre el arte español de la década de los cuarenta a través de las exposiciones", en Catálogo de la exposición Arte para después de una guerra, Consejería de Educación y Cultura, Madrid, 1993, pp. 74-75.
}

las columnas coronadas con antorchas, los obeliscos o los arcos de triunfo con águilas imperiales jalonaban los recorridos o servían de ornato al entorno, dando lugar a un arte escenográfico, mitad castrense y mitad cívico, símbolo del poder alcanzado por el nuevo régimen.

En el Departamento de Plásticas, junto a Morales también trabajaron jóvenes que, como él, habían militado durante la República en las filas del vanguardismo artístico y cultural, José Caballero, José Romero Escassi, Pedro Bueno, Emilio Aladrén, Teodoro Delgado y Pedro Pruna ${ }^{23}$. Todos ellos bajo la supervisión del falangista Juan Cabanas que, con José Aguiar y Carlos Ribera, fue uno de los artistas que más se interesó por dar una utilidad social al arte.

A la vista de lo dicho, es más que probable que Juan Antonio Morales acabara recibiendo el influjo Juan Cabanas, el pintor y cartelista falangista bajo cuyas órdenes trabajó. Y no sólo porque en sus obras notemos la influencia del Picasso neoclásico, sino porque como nos comenta Ángel Llorente:

"Juan Cabanas conoció directamente el Surrealismo en París, donde estuvo de 1926 a 1928, y la pintura metafísica y el Futurismo en Roma, donde residió en 1929. La escasa pintura que se conoce de este pintor, tras su vuelta a la Península $y$ hasta la guerra civil, presenta influencias de De Chirico y se puede encuadrar en el retorno al orden..." 24

En esta línea de retorno a lo latino, pero tremendamente ecléctico, se nos mues-

\footnotetext{
${ }^{23}$ Hay algunas fotografías que nos muestran a Morales, en el Departamento de Plásticas, trabajando también junto a Jose Luis López Sánchez, Llovet, Modesto y Jacinto Higueras, Fermín Sierra, Fernández Shaw o Jose Luis López Vázquez.

24 Á. LlORENTE, 1999, p. 48.
} 
tra Morales en otras dos pinturas, fechadas en 1942: Arlequín en paisaje ${ }^{25}$ (Lám.5) y Composición con desnudo, obras que parecen pedir su ampliación en una pared, como aquellas composiciones murales de tema clásico que a principios de los treinta aprendió a hacer en el estudio de Daniel Vázquez Díaz, su maestro (Escena clásica. Proyecto para mural, 1934); o como aquellas otras de Carlo Carrà en las que el artista italiano hacía un canto a los frescos de la Toscana y a los primitivos (Las hijas de Lot, 1919). ¿No serán estas obras del pintor español meros proyectos para composiciones murales?

"Tras la arquitectura, que se entendió como la manifestación suprema del arte estatal, -dice Ángel Llorente-, la pintura mural se consideró el arte más genuino del nuevo Estado, a pesar de que sus manifestaciones fueron escasas. Esta estimación, que durante la guerra había adelantado la Falange, era una interpretación fascista de la preocupación por hacer de la pintura un arte social que estuvo presente en la cultura artística europea de los años treinta, y que aunque apenas llegó a España, sí lo hizo con intensidad en Italia, país al que habían viajado algunos de los primeros ideólogos del fascismo español"26.

Una constante de ambas composiciones es el fondo de arquitectura clásica que vuelve a llevarnos, por un lado al De Chirico de los años veinte, autor de obras como La partida de los Argonautas (1921), y por otro, al grupo Novecento, que con mucha frecuencia recurrirá a estatuas y vestigios arquitectónicos sacados de la antigüedad. Pero a Morales le gusta teñir este orden y claridad de un halo de misterio; y prueba de ello es cómo sustituye la arquitectura por una endeble y extraña tramoya teatral $a$

${ }^{25}$ Presentada en JUMA con el no ${ }^{\circ} 10$, y el título: Pintura.

${ }^{26}$ Á. LLORENTE, 1999, pp. 47- 48. lo Magritte: largos cortinajes, profundas hornacinas, frontones descentrados o invertidos, atravesados por nubes ligeras $\mathrm{y}$ transparentes..., y en medio de este paisaje puramente mental y visionario, un arlequín de espaldas rodeado de seres sacados de un sueño italiano o una Venus de carne y hueso que nos mira desde su hornacina ${ }^{27}$.

Un tema que tampoco podía faltar en la exposición de JUMA era el del marinero. Ahora representado, en su obra El fantasma de la playa, de 1942 (Lám.6), como una figura estática y de espalda, que, en el mágico sosiego de su aislamiento, no parece inmutarse ante el paso fugaz de un espectro. Su pasividad, la ambigüedad del umbral donde se sienta, las inexplicables ataduras de sus brazos y el abrumador silencio que emana de esa playa desierta, parecen hablarnos de un sueño, pero también de ese mundo mágico teorizado por el alemán Franz Roh.

El marinero, al igual que el arlequín o el polichinela, sería en los años treinta un tema recurrente en el imaginario de muchos artistas, pensemos, por ejemplo, en el pintor surrealista Gregorio Prieto (Flor asesina, de 1933-1935) o en el italiano Gino Severini (Los jugadores de cartas, de 1924) ${ }^{28}$, (Lám.7).

En el caso de Morales, en sus obras anteriores a la guerra se nos muestra mucho más audaz, a la hora de reinterpretar la realidad, que en los años de la postguerra, y prueba de ello es su Marinero Ciego (Lám.8), fechado en 1932. Un óleo en el que, mez-

\footnotetext{
${ }^{27}$ Presentada en JUMA con el no 6 y el título: El marinero limitado.

${ }^{28}$ En 1921 SEVERINI publica su ensayo Du cubisme au classicisme. Esthétique du compas et du nombre, en el que abogaba por un nuevo clasicismo para la pintura, basado en la búsqueda de un lenguaje objetivo y riguroso, y que tendría gran repercusión entre los jóvenes artistas españoles, entre ellos el joven Dalí. [Traducción al castellano: Del cubismo al clasicismo, Murcia, Colección de Arquitectura no 25, 1993].
} 
clando citas cubistas y surrealistas, nos presentaba a un ser de cuerpo deforme, rostro extraño y ojos vacíos, que extendía con violencia sus manos tratando de alcanzar o huir de algo para nosotros desconocido. En El fantasma de la playa, sin embargo, pese a que sigue existiendo ese trasfondo de visión alucinante y onírica, ya no hay deformación ni violencia..., tan sólo silencio y quietud, magia y romántico misterio; y es que Morales, más que como realista o surrealista, aquí se nos muestra como un pintor de sugestiones poéticas, más cercano a lo germánico que a lo latino, o lo que es lo mismo, como un realista mágico ${ }^{29}$.

A la vista de lo dicho, queda ahora por ver cuál fue la respuesta de la crítica que acudió a JUMA, y si se cumplieron las expectativas del joven pintor. En general, casi todos los críticos coincidieron en señalar la pintura de los cuatro artistas noveles Morales, José Caballero, Víctor Cortezo y Luis Calzada-, como una muestra retrospectiva de su labor anterior, y, por ello, sólo válida como mero punto de partida, al tiempo que se les avisaba de que el camino elegido podía desembocar en un callejón sin salida: el del mero decorativismo.

En el caso de Morales hubo también quien ${ }^{30}$ censuró su empeño en recurrir a esa mitología vanguardista, nacida después de la I Guerra Mundial y que en aquel entonces ya se consideraba academia. Idea compartida por Rodríguez-Filloy que veía el conteni-

\footnotetext{
${ }^{29}$ En relación con esto, no hay que olvidar que este movimiento de vuelta a la figuración tendría cierta relación con el surrealismo no sólo porque Roh incluyera en él a Max Ernst, sino por la propia denominación de Realismo Mágico que se aplica posteriormente a la Nueva Objetividad, algo lógico si pensamos que el surrealismo rehabilita y concede poderes insólitos a los objetos dislocados por el cubismo y después rechazados por la abstracción.

${ }^{30}$ Vid. "Arte y Exposiciones. Pintura moderna", en Juventud, Madrid, junio-julio de 1942, p. 7.
}

do de sus obras como algo caedizo y remoto:

"Lienzos análogos, en los que se resolvían con talento las cuestiones insinuadas por Morales, despertaban en nosotros hace diez o doce años sensaciones concretas de una fugitiva belleza poética. Aquellos maniquíes simpáticos ante un paisaje latino, a los que Chirico, Carrá y Prieto había impregnado de una energía extraña, las estatuas mutiladas y las figuras de ambigua sustancia humana y pétrea, con fondo de decoración clásica, nos impresionan ahora con menos vive$z a^{\prime \prime 31}$.

¿Era, entonces, la poca actualidad de su pintura lo que llevaba a la crítica a tachar su obra de decorativista y superficial? Creemos más bien que las razones de ese rechazo estribaban en el convencimiento, por parte de los críticos -ya fueran conservadores o progresistas ${ }^{32}$, de que los movimientos de vanguardia habían sido nefastos para el arte.

Una prueba de lo que decimos la tenemos en Enrique Azcoaga, que consideraba que la pintura española debía encontrar su norte, alejándose tanto del realismo tradicional como de las vanguardias, y proponía la pintura velazqueña como arquetipo de verdad artística y ejemplo para los

${ }^{31}$ B. RODRÍGUEZ -FILlOY, "Cuatro pintores en la Casa JUMA", en Arriba, 5 de agosto de 1942.

${ }^{32}$ Según Ángel Llorente, la política estuvo presente en todos los críticos y, si bien la independencia era imposible, hubo algunos intentos de alejamiento del régimen, siendo el caso más significativo el de Enrique Azcoaga. Pero hasta 1944 puede hablarse de una crítica política, practicada por Miguel Moya Huertas, Tomás Borrás, Benito Rodríguez-Filloy, Samuel Ros, Cecilio Barberá. F. García Sanchiz, Manuel Pombo Angulo, Luis Gil Fillol, Manuel Sánchez Camargo y otros muchos. [Vid. Á. LLORENTE, Arte e ideología en el franquismo (1936-1951), La Balsa de la Medusa, Madrid, 1995, p. 225]. 
$\operatorname{artistas}^{33}$. Era previsible, por ello, que se mostrara igual de implacable respecto a JUMA:

"En la pintura de estos cuatro plásticos...-decía Azcoaga- hay una inhibición humana, una incapacidad para la sencillez [...]. Ayer, en el tiempo que esta pintura volvía loca a la gente, en los días que se escribían determinadas estéticas para determinados pintores, nos hubiera bastado con esta magia nueva...Pero hoy -como en tiempos de Zurbarán, de Velázquez, de Goya- un cuadro debe ser algo parecido a un milagro [...]. ¿Cuál es, entonces, el mensaje humano, profundo, palpitante de Caballero, Calzada y Morales? [...] ¿Hasta cuando, intervengan en pintura figuras humanas o no intervengan, un cuadro va a ser algo tan mudo, tan seco, tan decorativo, tan muertamente formal? " 34 .

Al hilo de esto hay que tener en cuenta que gran parte de los intelectuales falangistas, en su intento de encauzar la vanguardia hacia horizontes más clasicistas, no dudaron en mostrar su rechazo no sólo hacia la Segunda Escuela de Vallecas, sino hacia todo lo que les oliera a surrealismo, que como hemos visto es una cita recurrente en la obra de nuestro pintor.

Por otro lado, es posible que la razón de tan adversas críticas también haya que buscarla en la importancia que ahora se daba al asunto, por encima de cualquier búsqueda técnica o experimental.

"A tenor de los ideólogos fascistas dice Ángel Llorente- [...] el arte fascista se caracterizaría por ser claro, humano, espiritual y español. Por lo tanto, opuesto al arte de vanguardia, en cuanto oscu-

${ }^{33}$ Vid. Á. LLORENTE, 1995, pp. 248-249.

${ }^{34}$ E. AzCOAGA "Pinturas de José Caballero, Luis Calzada, Víctor María Cortezo y Juan Antonio Morales", en Informaciones, Madrid, 21 de julio de 1942. ro, deshumanizado, materialista e internacionalista" ${ }^{35}$.

Sin ir más lejos el crítico Manuel $\mathrm{Abril}^{36}$, que en su crónica había tratado con cierta displicente ironía a los jóvenes pintores de JUMA, llegó a proponer para las exposiciones oficiales grandes temas plásticos y humanos: el Cristianismo, la Maternidad, el Trabajo, la Amistad, la Patria, la Muerte, la Gloria, la Familia, la Castidad, la Alegría..., que no sólo enriquecerían al arte sino al público y a los artistas ${ }^{37}$.

Estaba claro que en 1942, en su primera exposición de la postguerra, en la que el pintor se mostraba totalmente enganchado a esa corriente de retorno al orden, la disparidad de gustos y propósitos con la crítica era evidente.

Por lo demás, en estos años, el joven pintor, como la mayoría de su colegas, alternaría su vocación pictórica con otras actividades, cuya única finalidad era la de poder subsistir. Encargos, no siempre realizados con ilusión, y en los que primaba la labor de dibujante: decorados de teatro, escenografías folklóricas, diseños de figurines..., casi todos en colaboración con Pepe Caballero $^{38}$. Una vertiginosa y absorbente

${ }^{35}$ Á. LLORENTE 1999, p. 47.

${ }^{36}$ Vid. M. ABRIL, "El papá y les enfants terribles", en Santo y Seña, Madrid, 30 de julio de 1942, pp. 6 -7.

${ }^{37}$ Vid. M. ABRIL, "Los grandes temas plásticos y humanos", en Arriba, Madrid, 16 de noviembre de 1941.

38 "Eran tiempos difíciles -decía Caballero-, donde la pintura que no era de primera necesidad apenas tenía mercado, y el poco que había era de otro signo, de clara regresión a un naturalismo. Aquella retaguardia en plena euforia triunfalista no estaba dispuesta a tolerar nada que le sonara a vanguardia y menos en pintura. Juan Antonio y yo comenzamos a colaborar de nuevo en las cosas que nos salían, que no eran muchas. Por aquella época hacíamos casi todos los espectáculos folklóricos que se presentaban en Madrid, en cuyos decorados tenía que aparecer siempre "la Giralda", se tratara del tema que fuera." [J. CABA- 
actividad, que no impidió que Morales siguiera luchando para encontrar un sitio en el panorama artístico madrileño, recurriendo en a ocasiones a los estamentos oficiales $^{39}$.

Prueba de ello será su participación, en mayo de 1943, en la Exposición de Autorretratos de Pintores Españoles (1800-1943), celebrada en el Museo de Arte Moderno de Madrid. A ella llevó su Autorretrato con Mandolina ${ }^{40}$ (Lám.9), de 1943, a juicio de algunos críticos, "...una de las obras más afortunadas de la exposición" ${ }^{\prime 41}$.

La fascinación que Morales sentía por el renacimiento italiano ${ }^{42}$ explica que le guste retratarse abrazando una mandolina, vestido a la usanza de aquella época y mostrando su perfil aguileño, pues siempre pensó que su nariz le daba un cierto aire italiano $^{43}$. En el aspecto técnico y compositivo, además de entroncar con los grandes

LLERO, catálogo de la exposición Homenaje a Juan Antonio Morales, 1984, p. 37].

${ }^{39}$ Sabemos que es ahora cuando realiza una tentativa frustrada para ser admitido en la Exposición Nacional de Bellas Artes de 1943, con una obra curiosamente inspirada en la estatuaria clásica romana: Equipo de Fútbol.

${ }^{40}$ En el catálogo de dicha exposición aparece reproducido en la p. 48 (lam. 79), bajo el título: Autorretrato.

${ }^{41}$ Vid. B. RODRÍGUEZ-FILlOY, "Exposición de Autorretratos", en Arriba, Madrid, 21 de mayo de 1943.

42 “... prefiero la moda del Renacimiento -decía Morales-, acaso porque quienes la reflejaron fueron sus grandes artistas: Ghirlandajo, Botticelli, Piero de la Francesca..., ellos nos dejaron la visión de una época llena de elegancia, [ ] ... por mi parte hubiera preferido también vestir a la moda de la gran época florentina. Y vivir en su ambiente, donde todo tenía el aliento renacentista, donde se ordenaba la vida bajo una preocupación estética que influía en todas las cosas..." [Palabras pronunciadas por JUAN ANTONIO MORALES en Radio Nacional de España, el 8 de septiembre de 1949].

${ }^{43}$ Esto parece justificar aquella frase de Manuel Pombo Angulo, que decía: “Este Morales siempre de perfil, a fuerza de volverse para captar los perfiles de las cosas..." [Vid. M. POMBO ANGUlO, "Homenaje a un pintor", en Ya, Madrid, 22 de junio de 1948]. maestros del Renacimiento italiano, desde Botticelli a Tiziano, pasando por Piero de la Francesca o Giorgione, se nutre también de ese caudal de citas y recuerdos aprendidos en los años de la preguerra, y que acabarán acercándolo a Daniel Vázquez Díaz (Retrato del escultor ruso Dimitri Tsapline, de 1934) ${ }^{44}$, o a Picasso (Autorretrato como arlequín en un café, de 1905), pintor este último que acabará sintonizando con el Novecento a través de Massimo Campigli, un artista que, aunque no perteneció al grupo milanés inicial, sí participó con ellos en una primera Mostra que tuvo lugar en Milán en 1926, y que suponía el comienzo del grupo Novecento italiano, nombre con el que M. Sarfatti rebautizó a la segunda fase de Novecento.

Italia una y otra vez, y ¿cómo no?, de nuevo el retorno al orden, esta vez llevado al campo del retrato, en donde un interesante abanico de artistas podrían haber servido de referencia a Morales. Desde el propio Massimo Campigli y su Mujer con los brazos cruzados, de 1924 (Lám. 10), al novecentista Mario Sironi, autor de obras como la titulada La discípula, de 1924, defensores ambos de ese ideal de simplicidad y solidez que caracteriza la tradición italiana. Son las suyas mujeres solitarias e idealizadas, de rasgos arcaizantes y en una pose similar a la de ciertos retratos renacentistas. Rasgos formales que también reconocemos en el

\footnotetext{
${ }^{44}$ Estos coqueteos con el neocubismo no le apartarán, sin embargo, de sus preocupaciones por el cromatismo y la luz. Colores aplicados como si fueran esmaltes, que van de los grises oxidados y marfiles sin lustre a los sepias fríos, y que el pintor emplea, yuxtaponiendo y manipulando materias, como un italiano del bajo Renacimiento, hasta obtener una pintura calcinada y sin aire. Pero hay algo más, y es ese silencio y esa absoluta inmovilidad que convierten al personaje en un objeto petrificado, que emerge de una noche mágica, de un paisaje profundo y oscuro por cuya lejanía cabalga silencioso un diminuto jinete ¿no hay algo de Uccello (Cacería nocturna, Ashmolean Museum, Oxford), o quizá de Parmigianino y de sus cielos crepusculares de luces inciertas (Madona del cuello largo, Uffizi, Florencia)?
} 
Autorretrato de Morales, en la actitud sosegada y hierática del personaje, en su rostro inexpresivo de mirada ausente y en el amaneramiento de sus manos que abrazan absurdamente una mandolina.

Terminamos el comentario de esta obra haciendo referencia a un artista español que creemos comparte una concepción de la pintura similar, en algunos aspectos, a la de nuestro pintor. Nos referimos a Luis Castellanos, quien pese a su prematura muerte, en 1946, a los 30 años, debió ejercer con sus teorías, recogidas en su texto Realidad y Realismo, ${ }^{45}$ cierto influjo en los ambientes frecuentados por Morales. Algo que no debe andar muy desencaminado si pensamos que Lafuente Ferrari ${ }^{46}$, consideró a Castellanos como el verdadero teórico de la generación del pintor.

En este sentido, para Gabriel Ureña la pintura de Castellanos, el único artista junto con Palencia que estuvo relacionado con las dos etapas de la Escuela de Valle$\operatorname{cas}^{47}$ :

"...tenía el eco de la quietud y calma de los dibujos de Alberto, pero era mucho más estática, más atemporal $y$, sobre todo, el intelecto dominaba sobre la frescura de la inspiración... Sus desnudos hipertrofiados, guitarras y arlequines tenían algo de inquietante y aterrador co-

${ }^{45}$ Texto publicado en Luis Castellanos, Colección Arte Moderno, nำ1, Madrid-Barcelona, 1946. Dicho texto fue leído por Castellanos en la inauguración de su exposición de pinturas y dibujos en el Museo de Arte Moderno de Madrid, el 7 de junio de 1946.

${ }^{46}$ Vid. E. LAFUENTE FERRARI, "Silueta de un pintor: Juan Antonio Morales", Clavileño, marzo-abril de 1952, no 14, p. 43.

${ }^{47}$ Ahora, entre fines de 1939 y 1942, Benjamín Palencia volvía a aglutinar en torno suyo a un nuevo Convivio o Escuela de Vallecas, bien diferente ya al que formara con Alberto antes de la guerra, sobre todo porque ahora buscará, en el paisaje no idealizado y en la pintura de género o naturalezas muertas, una vía de escape a la temática retórica imperante. locados en un vacío abrumador que amenazaba con hacer gravitar todo" ${ }^{\prime 48}$.

Así lo vemos en su Arlequín y venta$n a^{49}$ (1945) (Lám.11), una obra muy similar al autorretrato que ahora estudiamos, y que nos trae a la memoria estas palabras de su autor:

"Lentamente, creo que voy adentrándome en un nuevo modo de crear la realidad. Esta realidad me lleva sin cesar a preferir la sombra a la luz, el silencio al sonido, el vacío al volumen, la quietud al movimiento. Esta magia de lo negativo la siento como precursora de un estado de conciencia apto para hacer de la pintura no un juego, sino un acto reverente $y$ tremendo del espíritu" ${ }^{\prime \prime 50}$.

El resultado de esta manera de concebir la pintura bien podría haber sido este Autorretrato con mandolina, en donde esta figura petrificada en el espacio y en el tiempo, como congelada por un halo misterioso que la aleja de lo cotidiano, nos acerca en un plano más amplio, a la Nueva Objetividad y en la cercanía del paisanaje a ese mundo mágico de Castellanos y a su realidad inventada, fruto de un elaborado proceso mental.

"La experiencia se decanta -diría Morales unos años después-, los arrebatos se acendran ante el sentido reverencial de la sabiduría del oficio. Casi todos comenzamos a pintar alegremente, con una audacia tremenda; nos creemos que la pintura es un medio imitativo de la natura-

${ }^{48}$ Vid. G. UREÑA, Las Vanguardias Artísticas en la postguerra española 1940-1950, Madrid, Istmo, 1982, p. 55.

${ }^{49}$ Obra reproducida en R. CHAVARRI, Mito y realidad de la Escuela de Vallecas, Madrid, 1975, p. 62.

${ }^{50}$ L. CASTELLANOS, "Realidad y Realismo" [Vid. R. Chavarri, 1975, p.104; Vid. Catálogo de la exposición Luis Castellanos 1915-1946, Centro Cultural del Conde Duque, Madrid, 1996, p. 52]. 
leza, nada más; pero a medida que se va pintando, va saliendo a flote la verdad de cada uno y pasamos de una etapa afectiva e imaginativa a otra más racional"51.

En diciembre de 1944 Morales participa, junto a Serny y Tauler, en una exposición celebrada en la madrileña Sala Macarrón, y a la que entre otras obras llevó su Bodegón del saltamontes ${ }^{52}$ (c.1944) (Lám.12).

En esta ocasión, el joven vallisoletano parece inspirarse en los pintores españoles del Siglo de Oro: Sánchez Cotán, Felipe Ramírez, Meléndez o, como apunta Jaime Brihuega, en el propio Zurbarán, cuyo recuerdo "... se vuelve meditación visual equidistante de Sánchez Cotán y de Siro-

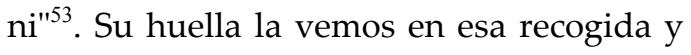
austera espiritualidad que sugieren estos sencillos frutos, y en el modo en que organiza los objetos, colocados en una ventana o fresquera fuertemente iluminada, lo que realza su presencia y plasticidad.

Pero, a diferencia de los oscuros bodegones de un Cotán, estas frutas ya granadas, este huevo, o este pequeño saltamontes..., objetos y seres sacados de nuestra cotidianeidad, pero que ahora se nos muestran envueltos en una luz remota, no nos producen una sensación de calma y sosiego místicos sino de enigma y misterio; algo que nos acerca de nuevo a Luis Castellanos y, sobre todo, a Franz Roh, cuando decía:

"[...] objetos que no pretenden moverse lo más minimo, y que, sin embargo, resultan inauditamente reales, extraños

51 Palabras de Juan Antonio Morales, recogidas por E. LAFUENTE FERRARI, "Silueta de un pintor: Juan Antonio Morales", en Clavileño, marzo-abril de 1952, p. 44.

${ }^{52}$ En el Catálogo de la exposición figura con el $\mathrm{n}^{\circ}$ 18 y bajo el título: Bodegón.

${ }^{53}$ J. BRIHUEGA, "El equipaje de los años treinta", en el catálogo de la exposición Tránsitos. Artistas españoles antes y después de la guerra civil, 1999, p. 37. esquemas misteriosos, $y$, sin embargo, visibles hasta en sus infimos detalles." 54 "[...] -realizar no es copiar sino rigurosamente edificar, construir los objetos, partiendo siempre de una representación interior, de su significación emocional, siendo el resultado una segunda creación: , pues- la naturaleza ha de ser captada por la visión con el mayor rigor posible, para... engullirla, digerirla y luego devolverla" ${ }^{\prime \prime 5}$.

Aunque Morales en su búsqueda del misterio se aproxime al Realismo Mágico, en la manera de llevarlo a cabo vuelve a acercarse al post expresionismo italiano, no sólo en la estudiada colocación de los objetos y en la presencia de elementos con un cierto sabor clásico y decorativo -la tela arrugada, el huevo...-, sino en la importancia que sigue dando a la materia áspera y esmaltada y al color captado siempre con una vibrante y fina sensibilidad, algo que vuelve a acercarlo a Carlo Carrà, para quien la forma, además de bien construida, debía mostrarse sensible a la situación espacial y lumínica.

En lo que a la crítica se refiere, hay que decir que, a tan sólo dos años de la exposición de JUMA, sus comentarios fueron ahora mucho más favorables para el artista, y una prueba la tenemos en estas palabras de Rodríguez-Filloy, antaño gran detractor del joven pintor:

"Una ligera reacción frente a la inicial posición estética suponen los cuadros presentados por Juan Antonio Morales. Al menos en algunos de ellos se advierte el decidido propósito de despojar a la creación de una buena parte de contenido literario [...] Hay ahora, dentro del tono sombrio y la concentración característicos, un mayor interés por las circunstan-

${ }^{54}$ F.RoH [traducción de Federico Vela], 1927, p. 37.

${ }^{55}$ F.ROH [traducción de Federico Vela], 1927, p. 56. 
cias del modelo y la expresión viva sin llegar a la descripción palpitante. El joven pintor -uno de los más inteligentes y capaces de su promoción-concede todavía una atención preferente a la plasticidad, la calidad táctil y noble y la materia, penetrada ahora de una luz extraña y recóndita. Estos aspectos prestan a sus retratos, desnudos, así como a su bodegón, una gran belleza, dentro siempre de sordas armonías y una gran austeri$\mathrm{dad}^{\prime \prime 56}$.

Creemos que este cambio de actitud se debe a que, ya por estas fechas y casi sin darse cuenta, su arte empezaba a caminar hacia un tipo de estética aceptada ya por un amplio sector de artistas jóvenes, deseosos de que la forma volviera a su sereno clasicismo y de que los movimientos desorbitados del arte moderno terminaran por desaparecer.

Con la exposición de Macarrón el largo viaje por la sombra parecía haber concluido, cerrándose todas aquellas actividades que el artista, un poco a tientas, había desarrollado a lo largo de estos cuatro años de la inmediata postguerra. A partir de ahora, su pintura empezará a decantarse hacia un tipo de eclecticismo moderado y fiel a la figuración, que hará que, al concluir 1944 , se le considere como uno de los pintores jóvenes más prometedores del panorama artístico madrileño ${ }^{57}$.

En este sentido, donde mejor va a reflejarse este eclecticismo al que Morales parecía aferrarse, será lógicamente en las exposiciones organizadas por la Academia

${ }^{56}$ Vid.B. RODRíGUEZ-FiLloY, "Exposición Tauler, Serny y Morales", Arriba, Madrid, 24 de diciembre de 1944.

${ }^{57}$ Vid. P. CASTILLA, "Las realidades de un año elocuente. El Arte de 1944 a 1945", en Arriba, Madrid, 1 de enero de 1945.
Breve de Crítica de Arte ${ }^{58}$, fundada en Madrid, en 1941, por el gran crítico y pensador Eugenio D'Ors, cuya intencionalidad iba a ser la de seleccionar obras de filiación postimpresionista o antirrealista que no renunciaran completamente a la figuración. Pese a todo, sus gustos, comparados con lo que se había hecho en España en los años treinta, eran bastante académicos, dado que su preocupación normativa por el clasicismo mediterráneo terminaría convirtiéndolo en el defensor a ultranza de la tradición: "Todo lo que no es tradición es plagio"59, había dicho.

El hecho de que este postimpresionismo poético y espíritu actual estuviera presente en la obra de Juan Antonio Morales, fue la razón de que la Academia le invitara a participar en el Tercer Salón de los Once $1945^{60}$, lo que supuso un gran espaldarazo para su carrera. Pero lo más curioso es que, pese a ser ésta su primera incursión en la Academia, sus pinturas ${ }^{61}$ fueron muy alabadas por la crítica; algo previsible tras hojear el libro Mis Salones, de D'Ors, y ver que las obras allí reproducidas, ${ }^{62}$ están muy

-

${ }^{58}$ Vid M.SÁnCheZ CAMARGO, Historia de la Academia Breve de Crítica de Arte. Homenaje a Eugenio D'Ors, Madrid, 1963, p. 14

${ }^{59}$ E. D'ORS, Mis Salones. Itinerario del Arte Moderno en España, Madrid, 1945, p. 27.

${ }^{60}$ En el III Salón de los Once 1945, celebrado en enero de 1946, en el Museo de Arte Moderno de Madrid, participaron, junto a Morales, José Caballero, Jaime de Dampierre, Marsá, González Moreno, Ricart, Eduardo Vicente, Zabaleta, Joaquín Vaquero y Angel Ferrant.

${ }^{61}$ A este Salón llevó cinco obras: el Bodegón del cardo muy cercano a la austera espiritualidad de Sánchez Cotán, un desnudo femenino muy clásico, una escena de playa de aire decimonónico, el busto de un torero, y un extraño autorretrato como decapitado.

${ }^{62}$ Bodegones de Nonell y desnudos femeninos, a veces de espaldas, de Sunyer o de Olga Sacharoff, escenas de marineros de Ramón de Campmani, arlequines y figuras clásicas de Picasso o de José de Tagores, damas decimonónicas de espaldas, mirándose a un espejo o con un abanico, de Emilio Grau Sala, o escenas clasicistas con arquitecturas extrañas de Juan Cabanas... 
en la línea de lo que Morales estaba haciendo por aquellas fechas. Algo que indicaba la profunda asimilación al entorno que se había producido en el joven pintor.

Terminamos ya estas reflexiones haciendo algunas matizaciones. En primer lugar, creemos que la idea más generalizada es que, para el arte, la guerra no supuso una completa ruptura respecto al pasado, pues, como bien dice Javier Tusell:

"... ni la memoria histórica de la vanguardia de los años veinte y treinta podía ser borrada, ni los propios artistas se sometieron a ello, ni se puede presumir una completa ruptura respecto al pasado, ni la reaparición de la vanguardia fue tan tardía como en ocasiones se ha pretendi$d 0^{\prime \prime 63}$.

¿Continuidad entonces? Quizá sí, pero ahora sin la ilusión de antaño, debido a esa clara conciencia de aislamiento, respecto a otros países, y con la certeza del escaso apoyo social que en estos primeros años del franquismo, tenía cualquier iniciativa de índole vanguardista.

Una continuidad que además hay que aceptar con reservas. Primero porque la propia estética vanguardista que triunfó en los años veinte y treinta no se caracterizó por ser algo fijo o codificado. Y segundo, porque nos enfrentamos a circunstancias $y$ personalidades muy diferentes. Hay casos, por ejemplo, en los que se acusa una continuidad de lenguajes tan clara, que es difícil saber si las obras fueron realizadas en la preguerra o en postguerra, pero jojo! esta continuidad puede ser sólo aparente, ya que tras la contienda muchos de estos lenguajes se impregnaron de un significado diferente.

${ }^{63}$ J.TUSSEL, "El ambiente cultural, político y artístico en el Madrid de la posguerra", en Catálogo de la exposición Arte para después de una guerra, 1993, p.66.
En el caso de Morales está claro que en la inmediata postguerra seguiría viviendo de esa herencia vanguardista: el surrealismo, Picasso, Vázquez Díaz... Pero esas corrientes que habían sido sinónimo de novedad en los años treinta ¿tenían ahora un sentido similar en los años cuarenta? Sinceramente, creemos que no.

"Así, por ejemplo, -como bien dice Jaime Brihuega- formas plásticas que antes de la guerra representaron paradigmas de la innovación pasaban a instalarse en los años cuarenta paradójicamente reinterpretadas bajo rúbricas inequívocamente conservadoras [...] Ocurrió básicamente con los realismos de nuevo cuño originarios de los años veinte y treinta, pero también con variedades surrealistas $y$ del metafisismo italianizante, con ciertas formas de expresionismo, etc." ${ }^{64}$.

Palabras que vienen a corroborar lo que ya dijimos al comienzo de este artículo, y es que el ideario plástico emanado de la Italia de entreguerras, $y$, en concreto, del entorno de la revista Valori plastici y el posterior grupo Novecento, fueron ahora, casi veinte años después de su eclosión, las corrientes que mejor se amoldaron al sentir general de gran parte de los artistas e intelectuales españoles de los años cuarenta, que, como la Italia de Mussolini, vivían una época de retorno a la gran tradición nacional.

Esto explica que, al igual que Morales, otros muchos jóvenes, acabarían creando un arte ecléctico, a base de mezclar citas diversas, antaño novedosas pero en su mayoría ahora adolecían del espíritu de búsqueda combativo e ilusionante que las vio nacer. Un eclecticismo que en el caso de Morales bebe de ese italianismo clasicista o neoclasicismo triunfal que en la vecina Italia se había convertido en sinónimo de arte del

${ }^{64}$ J. BRIHUEGA, 1999, p. 19. 
régimen, pero que al ser transplantado a la España de la inmediata postguerra no encierre una intención partidista o ideológica que sobrepase lo meramente estético.

Más bien, creemos que podría ser fruto de la propia inercia que a veces produce la moda, en este caso orientada a ese retorno al orden que el pintor español teñiría de un insinuante misterio. Una búsqueda de la utopía clásica que ahora se convierte en una valiosa alternativa para aquellos jóve-

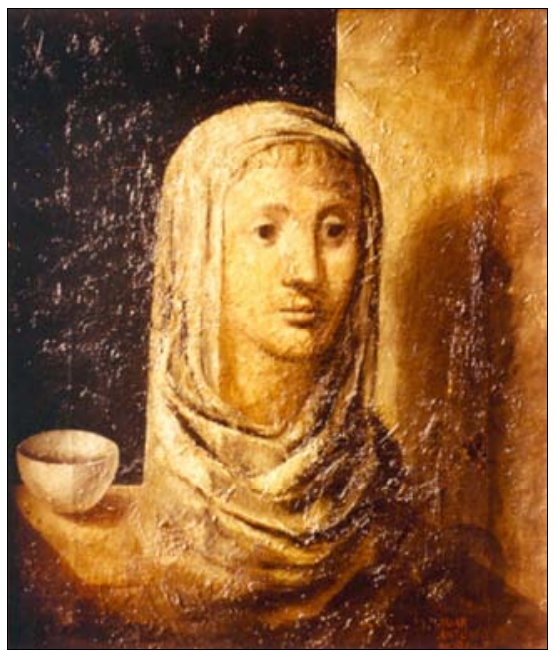

- Lám. 1. Juan Antonio Morales. Cabeza clásica (c.1941-1942). Madrid. Óleo sobre lienzo. 55 x $46 \mathrm{~cm}$. Herederos del pintor.

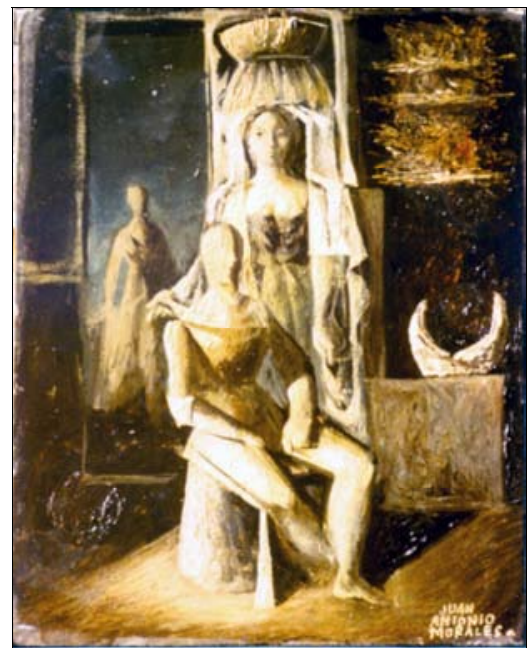

- Lám. 3. Juan Antonio Morales. Composición con figuras. (c.1941-1942). Madrid. Óleo sobre lienzo. Colección privada. Barcelona. nes artistas españoles que, aislados del exterior y sin saber con exactitud si lo que hacían, era, a escala europea, vanguardia o retaguardia, se habían visto obligados a improvisar, rehabilitando bajo el signo estético del eclecticismo los viejos idearios, y en donde a referencias vanguardistas, en ocasiones ya obsoletas, ahora se unirán todo un cúmulo de citas o imágenes procedentes de los países aliados del Régimen: de Alemania y, sobre todo, de la vecina Italia.

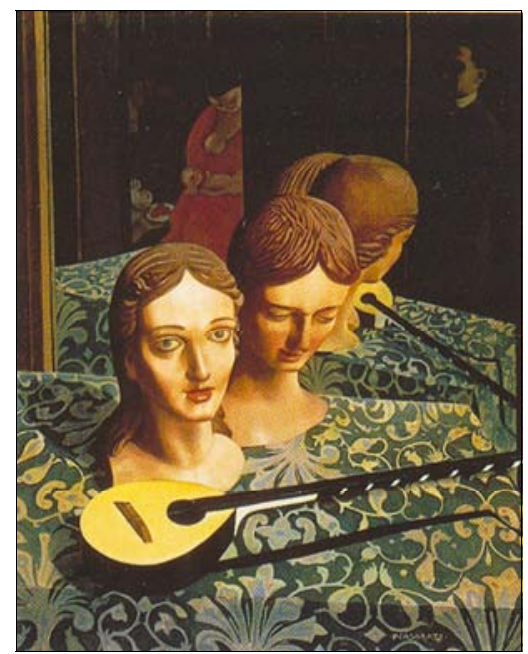

- Lám. 2. Felice Casorati. Naturaleza muerta con maniquíes (1924). Óleo sobre lienzo. 87 x $68 \mathrm{~cm}$. Civico Museo d'Arte Contemporanea, Milán.

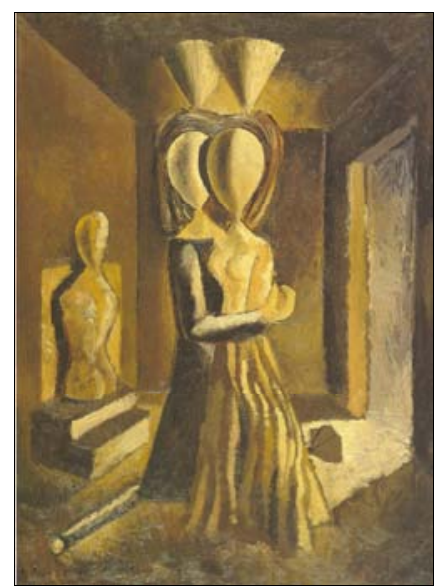

- Lám. 4. José Caballero. Interior con personajes (c.1945). Óleo sobre lienzo. 58'5 x $43 \mathrm{~cm}$. Fundación Eugenio Granell, Santiago de Compostela. 


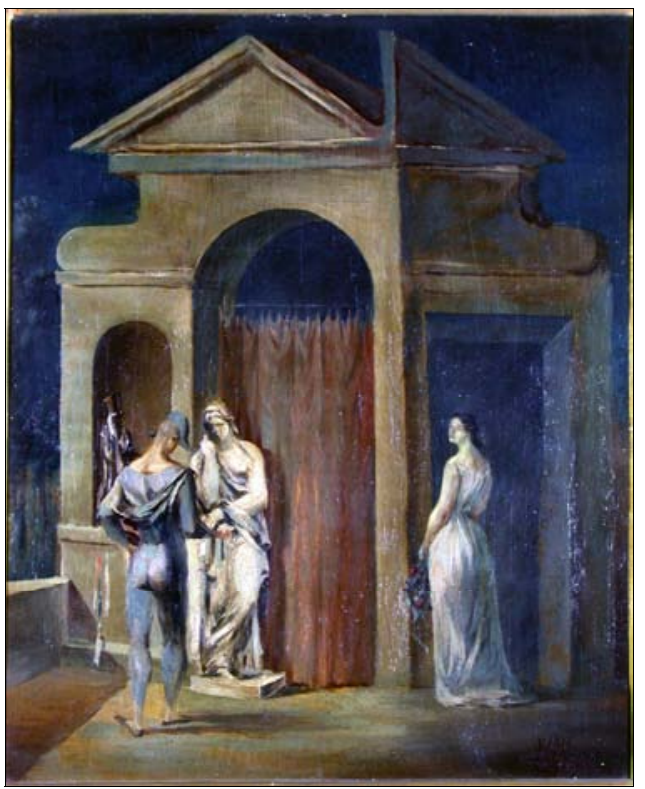

- Lám. 5. Juan Antonio Morales. Arlequín en paisaje. (c.1942). Madrid. Óleo sobre cartón. $34 \times 28 \mathrm{~cm}$. Colección privada. Madrid.

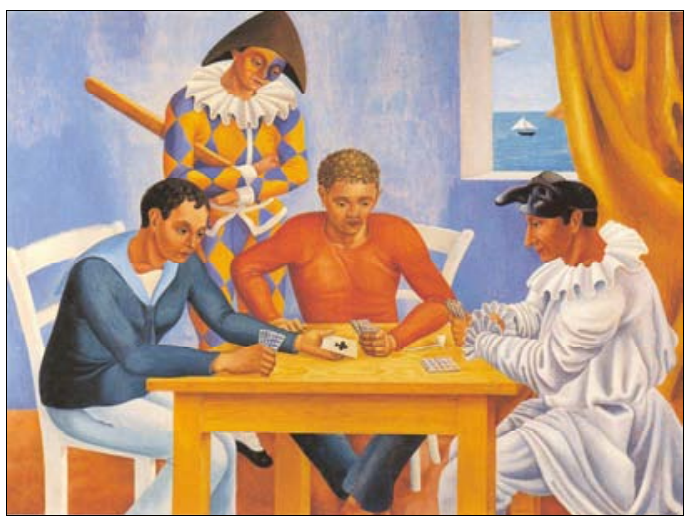

- Lám. 7. Gino Severino. Los jugadores de cartas. (1924). Óleo sobre tabla. 75,5 x $100 \mathrm{~cm}$. Colección particular, cortesía Galleria dello Scudo, Verona.

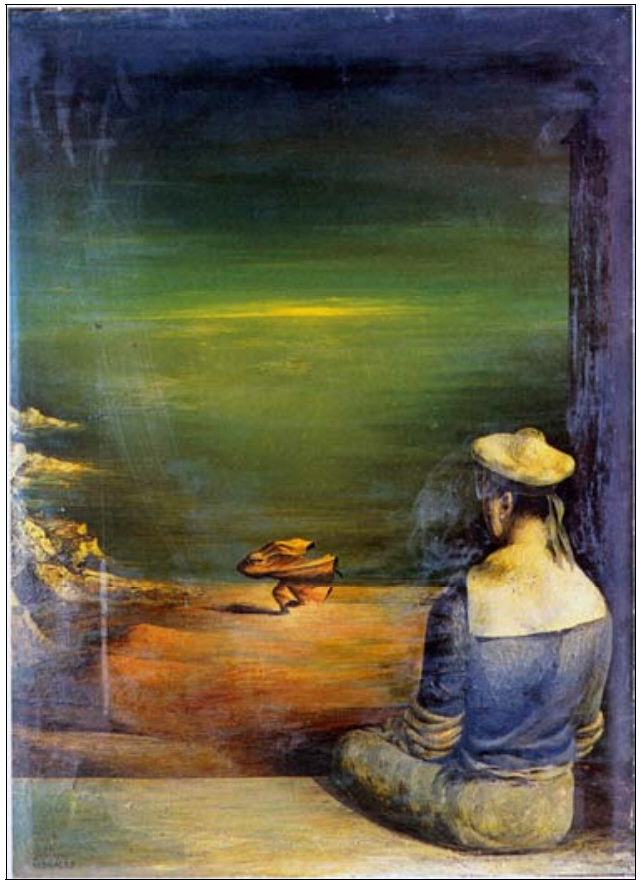

- Lám. 6. Juan Antonio Morales. El fantasma de la playa. 1942. Madrid. Óleo sobre lienzo. 73 x $52 \mathrm{~cm}$. Firmado en el ángulo inferior izquierdo. Colección privada. Madrid.

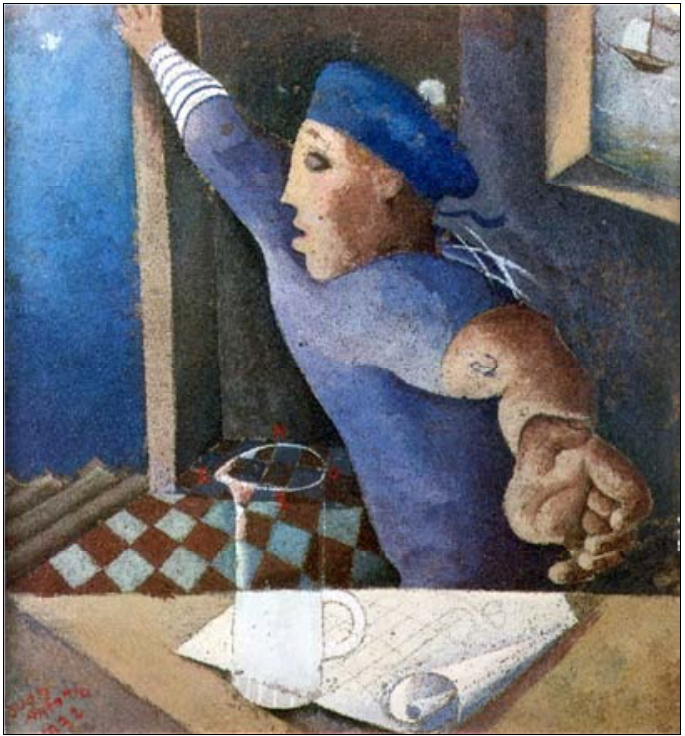

- Lám. 8. Juan Antonio Morales. El Marinero ciego. 1932. Madrid. Óleo y tierras sobre cartón. 22'5 x 22'5 cm. Colección privada. Madrid. 


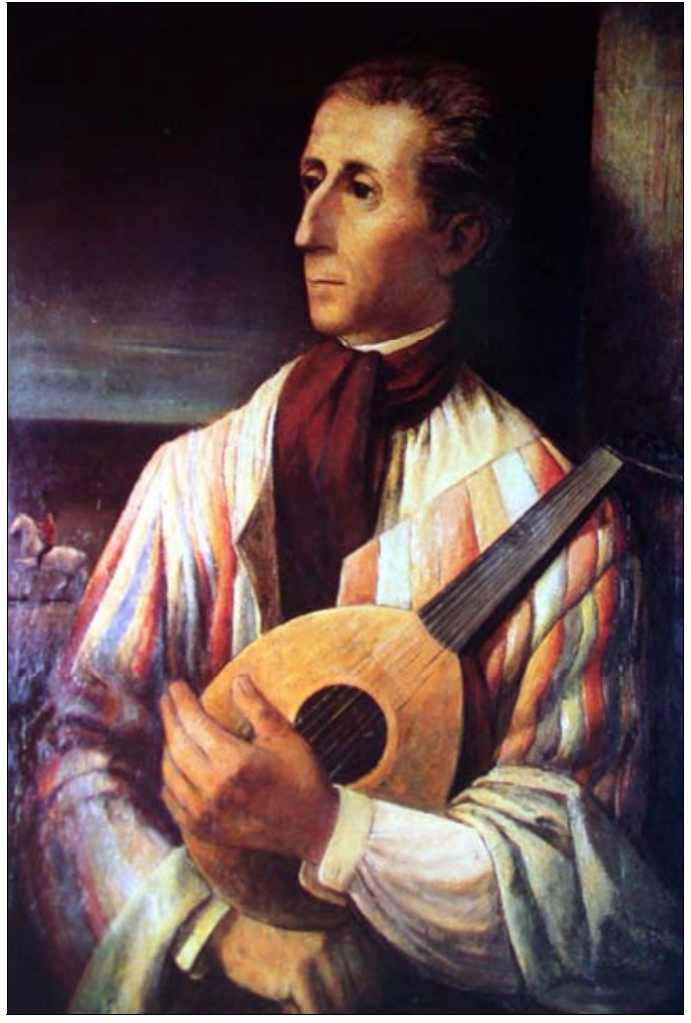

- Lám. 9. Juan Antonio Morales. Autorretrato con mandolina. 1943. Madrid. Óleo sobre tabla. $86 \times 60 \mathrm{~cm}$. Herederos del pintor.

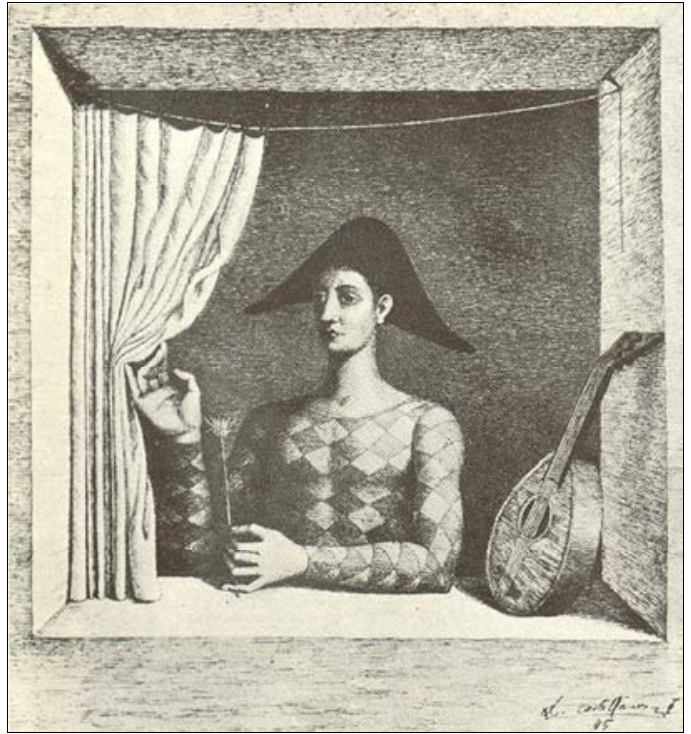

- Lám. 11. Luis Castellanos. Arlequín y ventana (1945). Dibujo. Paradero desconocido.

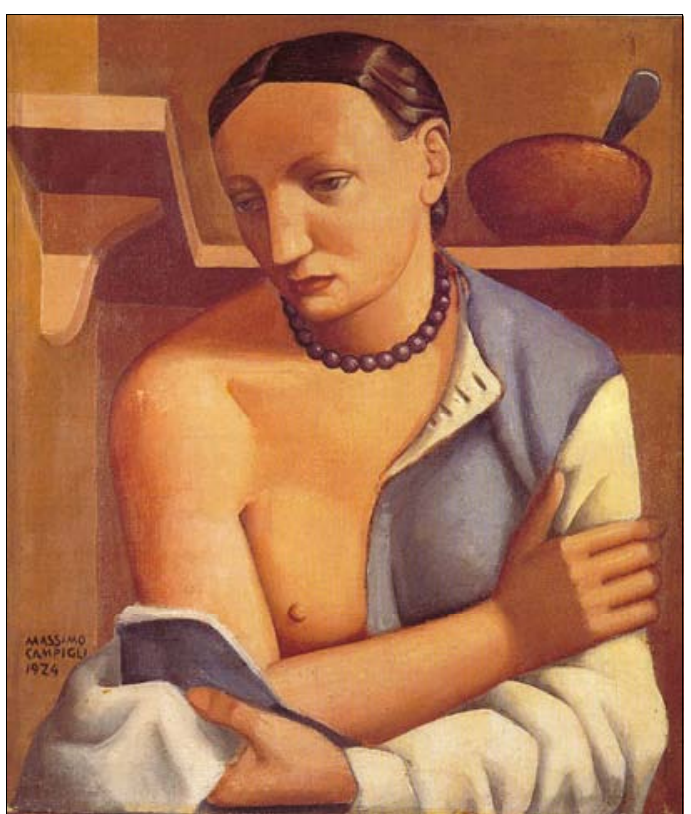

- Lám. 10. Massimo Campigli. Mujer con los brazos cruzados (1924). Óleo sobre lienzo. 55 x $46 \mathrm{~cm}$. Galleria Civica d'Arte Moderna e Contemporanea. Turín.

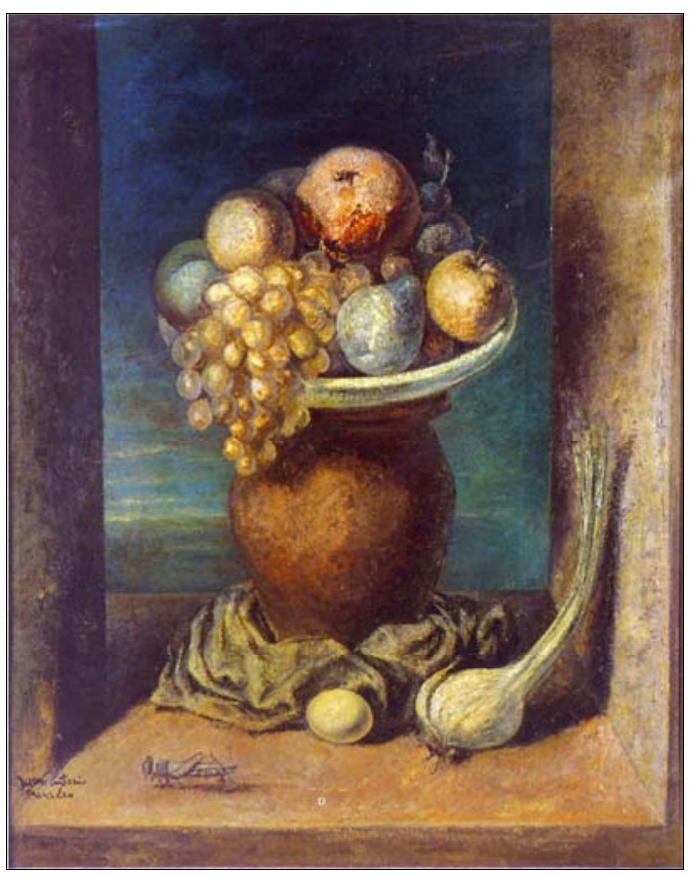

- Lám. 12. Juan Antonio Morales. Bodegón del saltamontes. c.1944. Madrid. Óleo sobre lienzo. 76 × $62 \mathrm{~cm}$. Colección privada. Madrid. 